\title{
Expression and Localization of Ryanodine Receptors in the Frog Semicircular Canal
}

\author{
Paola Perin, ${ }^{1}$ Laura Botta, ${ }^{1}$ Simona Tritto, ${ }^{2}$ and Umberto Laforenza ${ }^{3}$ \\ ${ }^{1}$ Department of Physiology, Section of General Physiology, University of Pavia, 27100 Pavia, Italy \\ ${ }^{2}$ Brain Connectivity Center, IRCCS Foundation National Neurological Institute C. Mondino, 27100 Pavia, Italy \\ ${ }^{3}$ Department of Physiology, Section of Human Physiology, University of Pavia, 27100 Pavia, Italy
}

Correspondence should be addressed to Umberto Laforenza, lumberto@unipv.it

Received 1 July 2011; Revised 5 October 2011; Accepted 11 October 2011

Academic Editor: Vickram Ramkumar

Copyright () 2012 Paola Perin et al. This is an open access article distributed under the Creative Commons Attribution License, which permits unrestricted use, distribution, and reproduction in any medium, provided the original work is properly cited.

\begin{abstract}
Several experiments suggest an important role for store-released $\mathrm{Ca}^{2+}$ in hair cell organs: drugs targeting $\mathrm{IP}_{3}$ and ryanodine (RyRs) receptors affect release from hair cells, and stores are thought to be involved in vesicle recycling at ribbon synapses. In this work we investigated the semicircular canal distribution of RyRs by immunofluorescence, using slice preparations of the sensory epithelium (to distinguish cell types) and flat mounts of the simpler nonsensory regions. RyRs were present in hair cells, mostly in supranuclear spots, but not in supporting cells; as regards nonsensory regions, they were also localized in dark cells and cells from the ductus. No labeling was found in nerve terminals, although nerve branches could be observed in proximity to hair cell RyR spots. The differential expression of RyR isoforms was studied by RT-PCR and immunoblotting, showing the presence of RyR $\alpha$ in both ampulla and canal arm and $\operatorname{RyR} \beta$ in the ampulla only.
\end{abstract}

\section{Introduction}

Despite being small and compact, hair cells display a great diversity of $\mathrm{Ca}^{2+}$-dependent processes, which appear to be largely independent of each other. $\mathrm{Ca}^{2+}$ ions may enter the hair cell through mechanoelectrical transduction channels, voltage-dependent channels, and neuronal nicotinic receptors [1]. In addition, synaptic transmission at both efferent [2] and afferent [3-5] synapses has been found to be modulated by intracellular $\mathrm{Ca}^{2+}$ stores in several hair cell organs. As regards afferent synapses, $\mathrm{Ca}^{2+}$ stores have been hypothesized to play a role in replenishing the reserve pool associated with ribbons [6]. Therefore, $\mathrm{Ca}^{2+}$ stores may be located as to "bridge" release and replenishment, acting as a positive feedback, where the more vesicles are released, the more are made available for release. In frog semicircular canal hair cells, the messages activating this feedback have been at least in part identified: $\mathrm{IP}_{3}$ receptors are activated by presynaptic metabotropic receptors which sense the glutamate released by hair cells [7], and ryanodinesensitive receptors (RyRs) are activated through CICR by the $\mathrm{Ca}^{2+}$ that entered through voltage-dependent $\mathrm{Ca}^{2+}$ channels, which are responsible for afferent release [3]. $\mathrm{Ca}^{2+}$-imaging recordings from frog canal hair cells showed that only selected $\mathrm{Ca}^{2+}$ hotspots, usually supranuclear, display $\mathrm{Ca}^{2+}$ induced $\mathrm{Ca}^{2+}$ release (CICR) behaviour, whereas in others $\mathrm{Ca}^{2+}$ just follows the timecourse of membrane depolarization [3]. The present work aims at giving a morphological basis for the physiological results, by studying RyR expression and localization in frog canal cells.

Ryanodine receptors are large tetrameric proteins localized to the membrane of intracellular calcium stores [8]. Three isoforms are known in mammals: RyR1 (mainly expressed in skeletal muscle), RyR2 (mainly expressed in cardiac muscle), and RyR3 (primarily found in neuronal tissue). In amphibia, only two isoforms have been clearly identified $[9,10]$ : RyR- $\alpha$ (homologous to RyR1) and RyR- $\beta$ (homologous to RyR3).

In the present work we have characterized the expression of RyRs in the frog semicircular canal, and their localization in both sensory and nonsensory cells. The latter have been included because of their role in the maintenance of endolymph ion composition and volume, which can affect hair cell function, and may be involved in several deafnessrelated mutations [11]. 


\section{Methods}

2.1. Animals. Experiments were carried out on canal preparations (ampullae, canal ducts, whole labyrinth), heart, brain, and skeletal muscle isolated from the frog Rana esculenta previously anesthetized, by immersion in $0.1 \%$ 3-aminobenzoic acid ethyl ester methane sulfonate solution (Sigma). Dissection of the labyrinth was performed as follows: after decapitation, the head was placed in a dissection dish, filled with Ringer solution, and the bulla was opened through a ventral approach. Membranous labyrinths were extracted by cutting the VIII nerve and the three canals and transferred to a second Ringer dish for further dissection. For homogenates, ampulla preparations contained the sensory crista with a short nerve stump, dark cell patches with associated transitional epithelium (see scheme in Figure 4), and the overlying wall, composed of connective and epithelium; canal arms contained the remaining tubular parts of semicircular canals, which do not contain any sensory structure. The characterization of canal duct cells appears difficult, since small variations in the length of the arm remaining attached to the ampulla could affect the presence of RyR-positive ductus cells. Whole labyrinth contained all structures from the membranous labyrinth, except for the removal of otoliths from the saccule. For RNA isolation, all steps from labyrinth extraction were performed at $0-4^{\circ} \mathrm{C}$, and RNaseOUT Recombinant Ribonuclease Inhibitor (Invitrogen) was added to the Ringer solution. Frogs were housed at the animal facility of the Department of Physiology, section of General Physiology, University of Pavia, cared for, and sacrificed according to the current European legal Animal Practice requirements.

2.2. RNA Isolation and Real-Time RT-PCR (qRT-PCR). Total RNA was extracted using the QIAzol Lysis Reagent (QIAGEN) from the heart, brain, and skeletal muscle of four frogs and from the inner ear of at least 50 frogs. Single cDNA was synthesized from RNA $(1 \mu \mathrm{g})$ using random hexamers and M-MLV Reverse Transcriptase (Invitrogen). Reverse transcription was always performed in the presence or absence (negative control) of the reverse transcriptase enzyme qPCR was performed in triplicate using $1 \mu \mathrm{g}$ cDNA, obtained as above indicated, and specific primers (intron-spanning primers) for RyR $\alpha$ (sense, $5^{\prime}$-CATTGTCATCCTGTTGGCCA-3'; antisense, $5^{\prime}$ CCTCATACGTCTTCCGGAAA- $3^{\prime}$ ) and RyR $\beta$ (sense, 5' -TGACCCCGATATGAAGTGTG-3'; antisense, $5^{\prime}$ GTGTGTTTCAAAGCCATGCG-3'). qPCR GreenMaster (Jena Bioscience) was used according to the manufacturer instruction and qPCR performed using Rotor Gene 6000 (Corbett). The conditions were as follows: initial denaturation at $95^{\circ} \mathrm{C}$ for $5 \mathrm{~min}, 40$ cycles of denaturation at $95^{\circ} \mathrm{C}$ for $30 \mathrm{~s}$, annealing at $58^{\circ} \mathrm{C}$ for $30 \mathrm{~s}$, and elongation at $72^{\circ} \mathrm{C}$ for $40 \mathrm{~s}$ [12]. The qRT-PCR reactions were normalized using ribosomal protein P1 mRNA (fp1) as housekeeping gene (sense, 5' ${ }^{\prime}$ TACGAGCGTCCATCACACAC-3'; antisense, 5' -AGACCAAAGCCCATGTCATC-3' ) [13].
Melting curves were generated to detect the melting temperatures of specific products immediately after the PCR run. The triplicate threshold cycles $(\mathrm{Ct})$ values for each sample were averaged resulting in mean $\mathrm{Ct}$ values for both the gene of interest and the housekeeping fpl gene. The gene $\mathrm{Ct}$ values were then normalized to the housekeeping gene by taking the difference: $\Delta \mathrm{Ct}=\mathrm{Ct}$ [gene] $-\mathrm{Ct}[\mathrm{fp} 1]$, with high $\Delta \mathrm{Ct}$ values reflecting low mRNA expression levels. First, the sequences of the bands were checked by using the BigDye terminator cycle sequencing kit (Applied Biosystem). PCR products were separated on a $3 \%$ NuSieve $(2: 1)$ agarose gel, stained with ethidium bromide, and acquired with the Image Master VDS (GE Healthcare Europe). The molecular weight of the PCR products was compared to the DNA molecular weight marker VIII (Roche Molecular Biochemicals).

2.3. Immunoblotting. Frog labyrinths, heart, brain, and skeletal muscle were homogenized by using a Dounce homogenizer in a solution containing $250 \mathrm{mM}$ Sucrose, $1 \mathrm{mM}$ EDTA, $10 \mathrm{mM}$ Tris-HCl, pH 7.6, $0.1 \mathrm{mg} / \mathrm{mL}$ PMSF, $100 \mathrm{mM} \beta$-mercaptoethanol, and Protease Inhibitor Cocktail (P8340, Sigma). The homogenates were solubilized in Laemmli buffer [14], and $50 \mu \mathrm{g}$ proteins was separated on 5\% SDS-polyacrylamide gel electrophoresis and transferred to the Hybond ECL Nitrocellulose Membrane (GE Healthcare) by electroelution. After $1 \mathrm{~h}$ blocking with Tris-buffered saline (TBS) containing 3\% BSA and $0.1 \%$ Tween (blocking solution) the membranes were incubated for $3 \mathrm{~h}$ at RT with the anti-RyR monoclonal antibody 34C (Affinity BioReagents) diluted 1:800 in the blocking solution. This antibody detects both alpha and beta frog isoforms [15]. The membranes were washed and incubated for $1 \mathrm{~h}$ with peroxidase-conjugated mouse $\operatorname{IgG}(1: 120000$ in blocking solution) (QED Bioscience). The bands were detected with ECL Advance Western Blotting Detection System (GE Healthcare).

2.4. Immunofluorescence. Canals dissected from frogs $(n=$ 7) were embedded in Jung Tissue Freezing Medium (Leica Microsystems) and immediately frozen in liquid nitrogen. Multiple $18 \mu \mathrm{m}$ cryostat sections were obtained from the frozen samples, washed with phosphate-buffered saline (PBS) solution, blocked for $60 \mathrm{~min}$ with bovine serum albumin (BSA) 3\%, rinsed with PBS and then incubated for 2 hours with $34 \mathrm{C}$ mouse anti-RyR monoclonal antibody (Affinity BioReagents), diluted 1:200 in PBS, plus, in colocalization experiments, T2200 rabbit anti-beta-tubulin III polyclonal antibody (Sigma), diluted 1: 100 in PBS. After three rinses in PBS ( $5 \mathrm{~min}$ ), the sections treated with primary antibodies were incubated (60 min at RT) with sheep antimouse IgG-FITC antibody (Sigma) and (for colocalizations) swine anti-rabbit IgG (whole molecule)-TRITC antibody (DakoCytomation), both at a dilution of $1: 1000$. Control experiments were performed simultaneously using preimmune serum or omitting the primary antibody. The slides were then mounted with Prolong Gold antifade reagent with DAPI (Invitrogen) and examined with a TCS SP2 LEICA 
confocal microscopy system equipped with a LEICA DM IRBE inverted microscope or a Nikon Eclipse 80i microscope.

2.5. Protein Content. Protein contents of all the samples were determined by Bradford's method using bovine serum albumin (BSA) as standard [16].

2.6. Statistics. All data are expressed as means \pm SEM. Statistical analysis of qRT-PCR experiments was primarily performed on $\Delta \mathrm{Ct}$ values. The significance of the differences of the means was evaluated with one-way ANOVA followed by Newman-Keuls $Q$ test or Student's $t$-test. All statistical tests were carried out with GraphPad Prism 4.00, 2003.

\section{Results}

3.1. qRT-PCR. The expression of RyRs in the frog semicircular canal was first verified by semiquantitative and quantitative RT-PCR. In mammals, three RyR isoforms (RyR1-3) are known, whereas in amphibia only two isoforms ( $\mathrm{RyR} \alpha$ and $\operatorname{RyR} \beta$ ) have been characterized, which are homologous to mammalian RyR1 and RyR3, respectively [17]. Cardiac myocytes from the frog atria express RyRs [9], but it is still unclear whether a distinct cardiac isoform, homolog to mammalian RyR2, exists in the frog. Figure 1 shows RT-PCR products for RyR $\alpha$ and $\operatorname{RyR} \beta$ in homogenates of frog semicircular canal ampulla (A), canal arm (C), whole labyrinth $(\mathrm{L})$, cardiac muscle $(\mathrm{H})$, brain $(\mathrm{B})$, and skeletal muscle $(\mathrm{M})$. The cDNAs for both isoforms were amplified using specific primers designed for the homolog sequences in Rana catesbeiana [10]. To rule out contamination from genomic DNA, negative reactions were set without reverse transcriptase (not shown); to test for cDNA yield and goodness, the expression of each RyR isoform was normalized to that of the housekeeping gene ribosomal protein P1 (fp1). Single bands of the expected size of cDNA fragments were amplified (RyR $\alpha, 329$ bp; RyR $\beta, 325$ bp; fp1, 356 bp, resp.). The results of agarose gel electrophoresis of representative PCR reaction products are shown in Figure 1(b). Negative controls $(\mathrm{Neg})$ were performed by omitting template.

RyR $\alpha$ was expressed by all investigated tissues. The relative quantitation of transcripts by qRT-PCR demonstrated the following expression order: $\mathrm{M} \gg \mathrm{B}>\mathrm{A}>\mathrm{C}=\mathrm{H}=\mathrm{L}$ $(P<0.05$, one-way ANOVA followed by Newman-Keuls $Q$ test; Figure 1(a)).

RyR $\beta$ isoform was expressed in all tissues except semicircular canal arms. RyR $\beta$ transcript was significantly higher in skeletal muscle and brain than in heart; lower amounts of mRNA were found in the ampulla and in the labyrinth $(P<0.05$, one-way ANOVA followed by Newman-Keuls $Q$ test Figure 1(a)).

3.2. Immunoblotting. To determine the expression of the RyR protein in the frog inner ear, total membrane homogenates were analyzed by immunoblotting with anti-RyR monoclonal antibody $34 \mathrm{C}$, an antibody that recognizes both alpha and beta isoforms [15]. In homogenates of whole labyrinth (L), cardiac muscle $(\mathrm{H})$, brain (B), and skeletal muscle

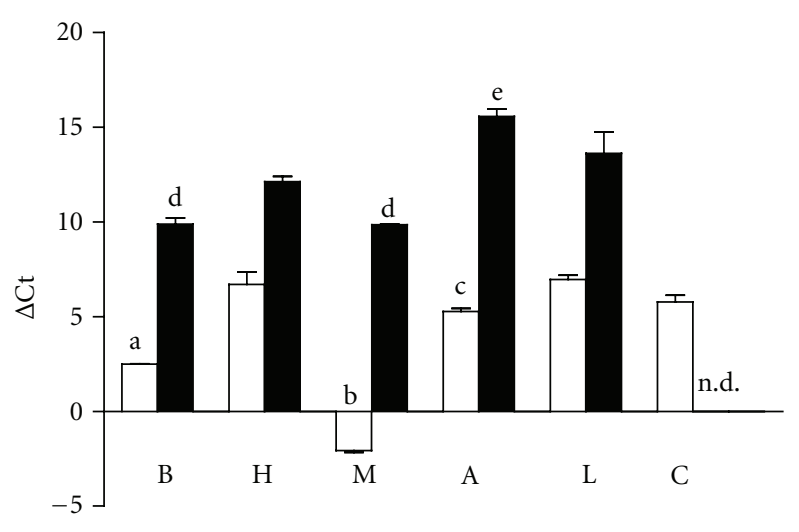

$\operatorname{RyR} \alpha$

$\operatorname{RyR} \beta$

(a)

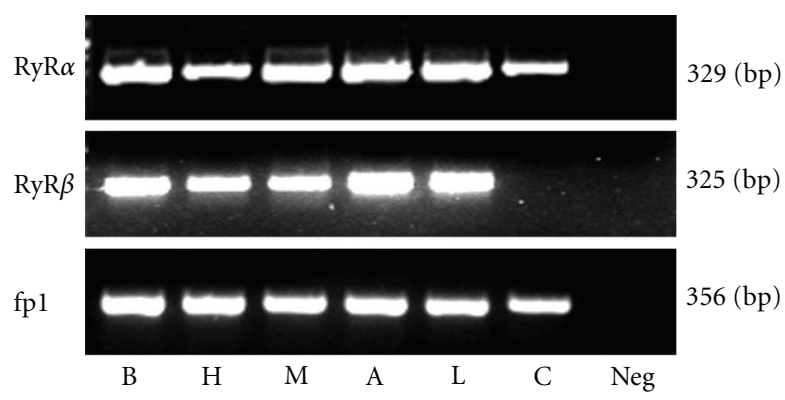

(b)

FIGURE 1: Expression of ryanodine receptor alpha $(\operatorname{Ry} R \alpha)$ and beta $(\operatorname{RyR} \beta)$ isoform mRNAs in brain $(B)$, heart $(\mathrm{H})$, skeletal muscle (M), semicircular canal ampulla (A), semicircular canal arm (C), and whole labyrinth (L) of the frog. (a) mRNA levels were measured by real-time polymerase chain reaction relative to the $\mathrm{fp} 1$ internal standard (see Materials and Methods), and the values obtained were reported as $\Delta \mathrm{Ct}$. Bars represent the mean \pm SEM of at least 4 different experiments, each from different RNA extracts. a, $P<$ 0.001 versus $\mathrm{H}, \mathrm{A}, \mathrm{L}, \mathrm{C}$; b, $P<0.001$ versus $\mathrm{B}, \mathrm{H}, \mathrm{A}, \mathrm{L}, \mathrm{C}$; $\mathrm{c}$, $P<0.05$ versus $\mathrm{H}, \mathrm{L}$; d, $P<0.05$ versus $\mathrm{H}, \mathrm{A}, \mathrm{L} ; \mathrm{e}, P<0.05$ versus $H, L$. (one-way ANOVA followed by Newman-Keuls $Q$ test). n.d., not detected. When not present, SEM was within the symbol area. Note that high $\Delta \mathrm{Ct}$ values reflect low mRNA expression levels. (b) Gel electrophoresis of PCR products. The PCR products were of the expected size: RyR $\alpha, 329$ bp; RyR $\beta, 325$ bp; fp1, 356 bp. Neg: reaction without template. Similar results were obtained from at least four different frog RNA extracts.

(M), a doublet is seen at $565 \mathrm{kDa}$ representing the alpha and beta isoforms of the receptor (Figure 2). To parallel qPCR experiments, RyR expression was further investigated in homogenates of purified canal arms and ampullae. As expected, ampulla samples showed both RyR bands. As regards canal arms, expression was instead very faint or missing (Figure 2).

3.3. Immunofluorescence. Cellular localization of RyRs receptors was investigated with immunofluorescence confocal microscopy using affinity-purified antibodies. RyRs were 


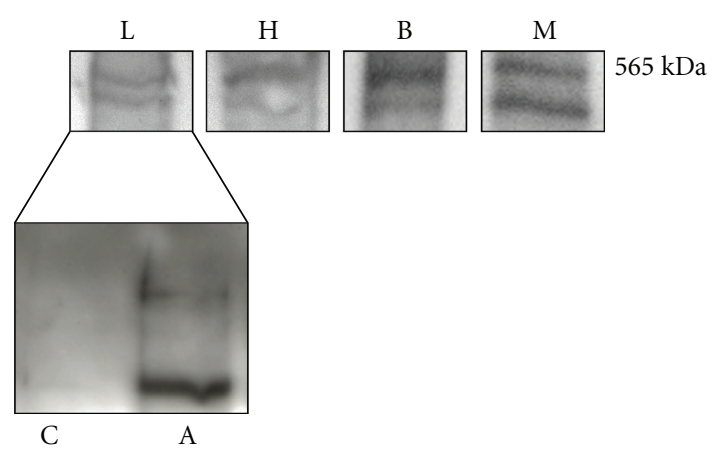

FIgURE 2: Ryanodine receptor alpha $(\operatorname{RyR} \alpha)$ and beta $(\operatorname{RyR} \beta)$ protein expression in homogenates of whole labyrinth (L), semicircular canal ampulla (A), semicircular canal arm (C), cardiac muscle $(\mathrm{H})$, brain (B), and skeletal muscle (M). Lanes were loaded with $50 \mu \mathrm{g}$ of proteins, probed with a non-isoform-specific mouse monoclonal anti-ryanodine antibody (34C) diluted 1:800 and processed as described in Materials and Methods. Blots were acquired with the Image Master VDS (Amersham Biosciences Europe, Italy). All tissues (except for $\mathrm{C}$ ) displayed two major bands corresponding to the alpha and beta isoforms, respectively. No bands were detected when anti-ryanodine antibody was omitted or substituted by nonimmune serum (not shown). Blots representative of four were shown.

found in the crista sensory epithelium (Figure 3); in particular, puncta were evident in the perinuclear/supranuclear region of most hair cells, whereas no labeling was observed below the sensory epithelium. Double labelling with betatubulin, which stains vestibular nerve fibers up to synaptic terminals [18], showed that RyR spots were not colocalized with terminals (and therefore most likely located in hair cells) but could be in close apposition to them (asterisks), suggesting a role in afferent transmission at a subpopulation of synapses. As regards nonsensory regions, a faint homogeneous RyR labeling was observed in dark cells (Figure 4), but not in transitional cells (Figure 4). As regards canal duct cells, a perinuclear formation (Figure 4) was evident in a subpopulation of cells located at the entrance of the canal arm. These cells were difficult to observe, given the semicircular canal topology, since they only encompassed a strip in the proximal region of the arm. In colocalizations, no nerve fibers were observed in these nonsensory regions (not shown).

\section{Discussion}

Our data show the expression of RyRs in the frog semicircular canal, in both sensory and nonsensory structures. As regards the former, RyRs are expressed in hair cells but not in afferent fibers. This is in agreement with physiological data [3] suggesting that the ryanodine-sensitive mechanisms involved in afferent transmission are presynaptic.

Since the antibody used for RyR localization does not discriminate between $\operatorname{Ry} R \alpha$ and $\operatorname{RyR} \beta$, it is not clear whether both isoforms are coexpressed in hair cells. In fact, rat cochlear outer hair cells express RyR1 [4], which

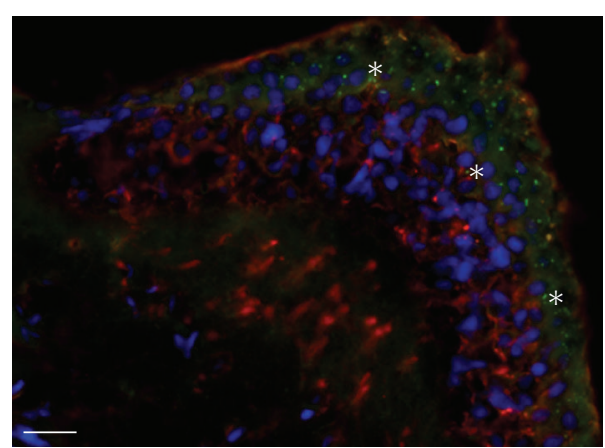

FIGURE 3: Distribution of RyRs in the frog Crista ampullaris. Representative immunofluorescence obtained from $18 \mu \mathrm{m}$ thick crista slices. Tissues were treated with monoclonal anti-RyR antibodies (green) and polyclonal anti-tubulin beta III antibodies (red); nuclei were counterstained blue with DAPI. Labelling for RyR was observed in hair cells but not in nerve fibers, whereas the opposite pattern was observed for tubulin (except for a faint staining at the apex). Labeling for RyRs appeared to be stronger in spots above the hair cell nuclei; no clear difference was noted among crista regions. In several regions (asterisks), tubulin-positive nerve arborizations came close to RyR-positive spots. The micrographs are representative of seven separate experiments. Bar: $20 \mu \mathrm{m}$.

is homologous to frog $\mathrm{RyR} \alpha$ [17], whereas rat vestibular epithelia appear to express all three RyR isoforms [19].

As regards their properties, RyR1 and $\operatorname{RyR} \alpha$ [17] are unique in their ability to physically interact with ion channels in the plasma membrane, such as L-type voltage-dependent $\mathrm{Ca}^{2+}$ channels [20] and thus open in response to their opening, regardless of $\mathrm{Ca}^{2+}$ increase (DICR, depolarizationinduced $\mathrm{Ca}^{2+}$ release). On the other hand, $\mathrm{RyR} \beta$ is able to support $\mathrm{Ca}^{2+}$-induced $\mathrm{Ca}^{2+}$ release (CICR). In frog skeletal muscle, where both $\alpha$ and $\beta$ isoforms are expressed, $\operatorname{RyR} \alpha$ induced sustained $\mathrm{Ca}^{2+}$ increases, whereas $\mathrm{RyR} \beta$ induced oscillations $[15,21]$. Physiological data in frog canal hair cells show the presence of an active CICR process for prolonged depolarization [3]; spontaneous oscillations of intracellular $\mathrm{Ca}^{2+}$ have also been sometimes observed (P.P. personal communication). It is therefore likely that both receptors are present in hair cells. One interesting feature of RyR expression in hair cells is the presence of clusters, mainly in the supranuclear part of the cell ([3], this work); $\mathrm{IP}_{3}$ receptors are instead found throughout the cell [5]. This distribution could endow a single hair cell with several synaptic pools with differential modulation or different adaptation properties. As an additional possible role for RyRs in frog vestibular hair cells, fast CICR (or DICR) could amplify presynaptic $\mathrm{Ca}^{2+}$ increases, thus allowing the release of more vesicles than predicted by the size of membrane $\mathrm{Ca}^{2+}$ currents, as was observed in the saccule [22]. Fast CICR has not been documented in canal hair cells, but it could be present, especially in phasic cells, which are more sensitive to high-frequency stimuli.

As regards nonsensory structure, RyRs were observed in cells that secrete $\mathrm{K}^{+}$(dark cells) and $\mathrm{Cl}^{-}$(ductus cells) into the endolymph [9], but not in transitional cells, which 

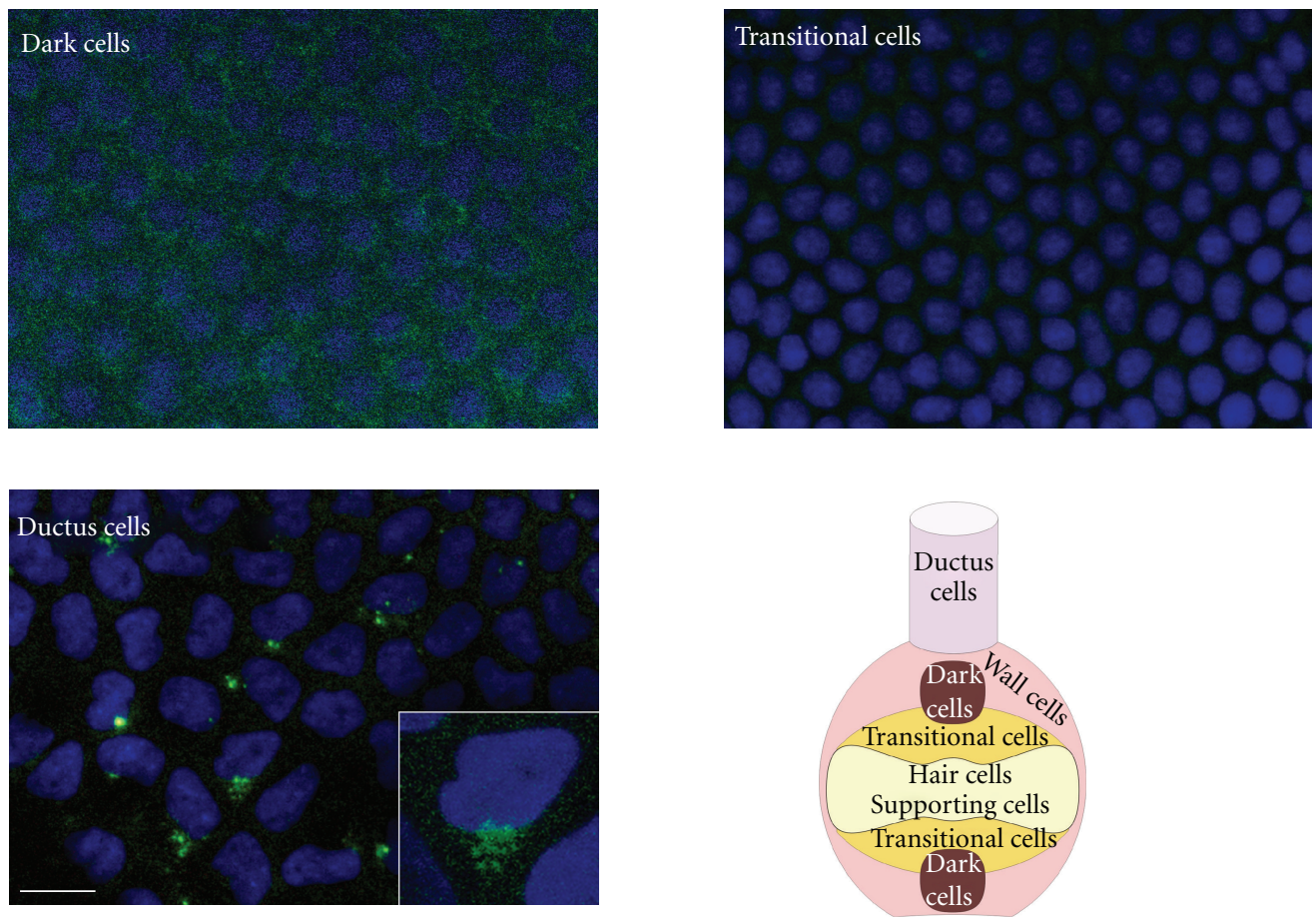

FIGURE 4: Distribution of ryanodine receptors (RyRs, green) in nonsensory epithelia of the frog canal. Representative immunofluorescence confocal stacks obtained from dark cells, transitional cells, and ductus cells. Both dark cells and ductus cells were positive for RyR, whereas labeling of transitional cells was absent or faint. In ductus cells, RyRs appear localized to a perinuclear formation. Inset shows a single cell at higher magnification. The micrographs are representative of six separate experiments. Bar: $20 \mu \mathrm{m}$. A schematic representation of the distribution of different epithelial cell types in the semicircular canal is also shown.

reabsorb $\mathrm{Na}^{+}$[23]. Pharmacological experiments will be needed to clarify whether store release is involved in the endocrine regulation of these cells (e.g., by adrenaline) [24].

\section{Conclusions}

In this study, we investigated the expression and distribution of RyRs in the frog semicircular canal. RT-PCR data show the presence of $\operatorname{RyR} \alpha$ and $\operatorname{RyR} \beta$ in the ampulla and a faint expression of $\operatorname{RyR} \alpha$ in the canal duct. Immunolabeling of the sensory epithelium shows the presence of RyRs in hair cells; no labeling was instead found in nerve fibers, supporting cells, and connective tissue. The presence of RyRs in frog canal hair cells supports previous physiological data displaying ryanodine-sensitive CICR in the same cells; moreover, most RyR spots, similarly to CICR hotspots, were supranuclear, suggesting the presence of different synaptic populations within the same hair cells. Finally, finding $\mathrm{Ca}^{2+}$ stores in nonsensory cells involved in ion and water regulation suggests a pathway for controlling the regulation of endolymph volume and composition.

\section{Authors' Contribution}

P. Perin and L. Botta contributed equally to this paper.

\section{Acknowledgment}

This research was funded in part by AIT (Associazione Italiana Tinnitus) ONLUS.

\section{References}

[1] F. Mammano, M. Bortolozzi, S. Ortolano, and F. Anselmi, "Ca ${ }^{2+}$ signaling in the inner ear," Physiology, vol. 22, no. 2, pp. 131-144, 2007.

[2] M. Lioudyno, H. Hiel, J. H. Kong et al., "A "synaptoplasmic cistern" mediates rapid inhibition of cochlear hair cells," Journal of Neuroscience, vol. 24, no. 49, pp. 11160-11164, 2004.

[3] A. Lelli, P. Perin, M. Martini et al., "Presynaptic calcium stores modulate afferent release in vestibular hair cells," Journal of Neuroscience, vol. 23, no. 17, pp. 6894-6903, 2003.

[4] M. Beurg, A. Hafidi, L. J. Skinner et al., "Ryanodine receptors and BK channels act as a presynaptic depressor of neurotransmission in cochlear inner hair cells," European Journal of Neuroscience, vol. 22, no. 5, pp. 1109-1119, 2005.

[5] M. L. Rossi, I. Prigioni, L. Gioglio et al., "IP3 receptor in the hair cells of frog semicircular canal and its possible functional role," European Journal of Neuroscience, vol. 23, no. 7, pp. 1775-1783, 2006.

[6] M. E. Schnee, J. Santos-Sacchi, M. Castellano-Muñoz, J. H. Kong, and A. Ricci, "Calcium-dependent synaptic vesicle trafficking underlies indefatigable release at the hair cell afferent fiber synapse," Neuron, vol. 70, no. 2, pp. 326-338, 2011. 
[7] A. W. Hendricson and P. S. Guth, "Transmitter release from Rana pipiens vestibular hair cells via mGluRs: a role for intracellular $\mathrm{Ca}^{++}$release," Hearing Research, vol. 172, no. 12, pp. 99-109, 2002.

[8] D. Rossi and V. Sorrentino, "Molecular genetics of ryanodine receptors $\mathrm{Ca}^{2+}$-release channels," Cell Calcium, vol. 32, no. 5-6, pp. 307-319, 2002.

[9] P. Tijskens, G. Meissner, and C. Franzini-Armstrong, "Location of ryanodine and dihydropyridine receptors in frog myocardium," Biophysical Journal, vol. 84, no. 2, part 1, pp. 1079-1092, 2003.

[10] H. Oyamada, T. Murayama, T. Takagi et al., "Primary structure and distribution of ryanodine-binding protein isoforms of the bullfrog skeletal muscle," Journal of Biological Chemistry, vol. 269, no. 25, pp. 17206-17214, 1994.

[11] P. Wangemann, "Supporting sensory transduction: cochlear fluid homeostasis and the endocochlear potential," Journal of Physiology, vol. 576, no. 1, pp. 11-21, 2006.

[12] U. Laforenza, G. Gastaldi, M. Polimeni et al., "Aquaporin-6 is expressed along the rat gastrointestinal tract and upregulated by feeding in the small intestine," BMC Physiology, vol. 9, no. 1, article 18, pp. 1-12, 2009.

[13] R. Meccariello, M. F. Franzoni, R. Chianese et al., "Interplay between the endocannabinoid system and GnRH-I in the forebrain of the anuran amphibian Rana esculenta," Endocrinology, vol. 149, no. 5, pp. 2149-2158, 2008.

[14] U. K. Laemmli, "Cleavage of structural proteins during the assembly of the head of bacteriophage T4," Nature, vol. 227, no. 5259, pp. 680-685, 1970.

[15] T. Kashiyama, T. Murayama, E. Suzuki, P. D. Allen, and Y. Ogawa, "Frog $\alpha$ - and $\beta$-ryanodine receptors provide distinct intracellular $\mathrm{Ca}^{2+}$ signals in a myogenic cell line," PLoS One, vol. 5, no. 7, Article ID e11526, 2010.

[16] M. M. Bradford, "A rapid and sensitive method for the quantitation of microgram quantities of protein utilizing the principle of protein dye binding," Analytical Biochemistry, vol. 72, no. 1-2, pp. 248-254, 1976.

[17] J. Zhou, B. S. Launikonis, E. Ríos, and G. Brum, "Regulation of $\mathrm{Ca}^{2+}$ sparks by $\mathrm{Ca}^{2+}$ and $\mathrm{Mg}^{2+}$ in mammalian and amphibian muscle. An RyR isoform-specific role in excitationcontraction coupling?" Journal of General Physiology, vol. 124, no. 4, pp. 409-428, 2004.

[18] B. Perry, H. C. Jensen-Smith, R. F. Ludueña, and R. Hallworth, "Selective expression of $\beta$ tubulin isotypes in gerbil vestibular sensory epithelia and neurons," Journal of the Association for Research in Otolaryngology, vol. 4, no. 3, pp. 329-338, 2003.

[19] P. Cameron, S. Gaboyard, S. D. Price, M. Klapczynski, D. Modi, and A. Lysakowski, "Multiple isoforms of ryanodine and IP3 receptor genes expressed in rat inner ear organs," Molecular Biology Deafness Hearing, p. 160, 2004.

[20] C. S. Haarmann, A. F. Dulhunty, and D. R. Laver, "Regulation of skeletal ryanodine receptors by dihydropyridine receptor II-III loop C-region peptides: relief of $\mathrm{Mg}^{2+}$ inhibition," Biochemical Journal, vol. 387, no. 2, pp. 429-436, 2005.

[21] T. Murayama and N. Kurebayashi, "Two ryanodine receptor isoforms in nonmammalian vertebrate skeletal muscle: possible roles in excitation-contraction coupling and other processes," Progress in Biophysics and Molecular Biology, vol. 105, no. 3, pp. 134-144, 2011.

[22] B. W. Edmonds, F. D. Gregory, and F. E. Schweizer, "Evidence that fast exocytosis can be predominantly mediated by vesicles not docked at active zones in frog saccular hair cells," Journal of Physiology, vol. 560, no. 2, pp. 439-450, 2004.
[23] J. H. Lee, T. Chiba, and D. C. Marcus, "P2X2 receptor mediates stimulation of parasensory cation absorption by cochlear outer sulcus cells and vestibular transitional cells," Journal of Neuroscience, vol. 21, no. 23, pp. 9168-9174, 2001.

[24] P. G. Milhaud, S. R. Pondugula, J. H. Lee et al., "Chloride secretion by semicircular canal duct epithelium is stimulated via $\beta 2$-adrenergic receptors," American Journal of PhysiologyCell Physiology, vol. 283, no. 6, pp. C1752-C1760, 2002. 

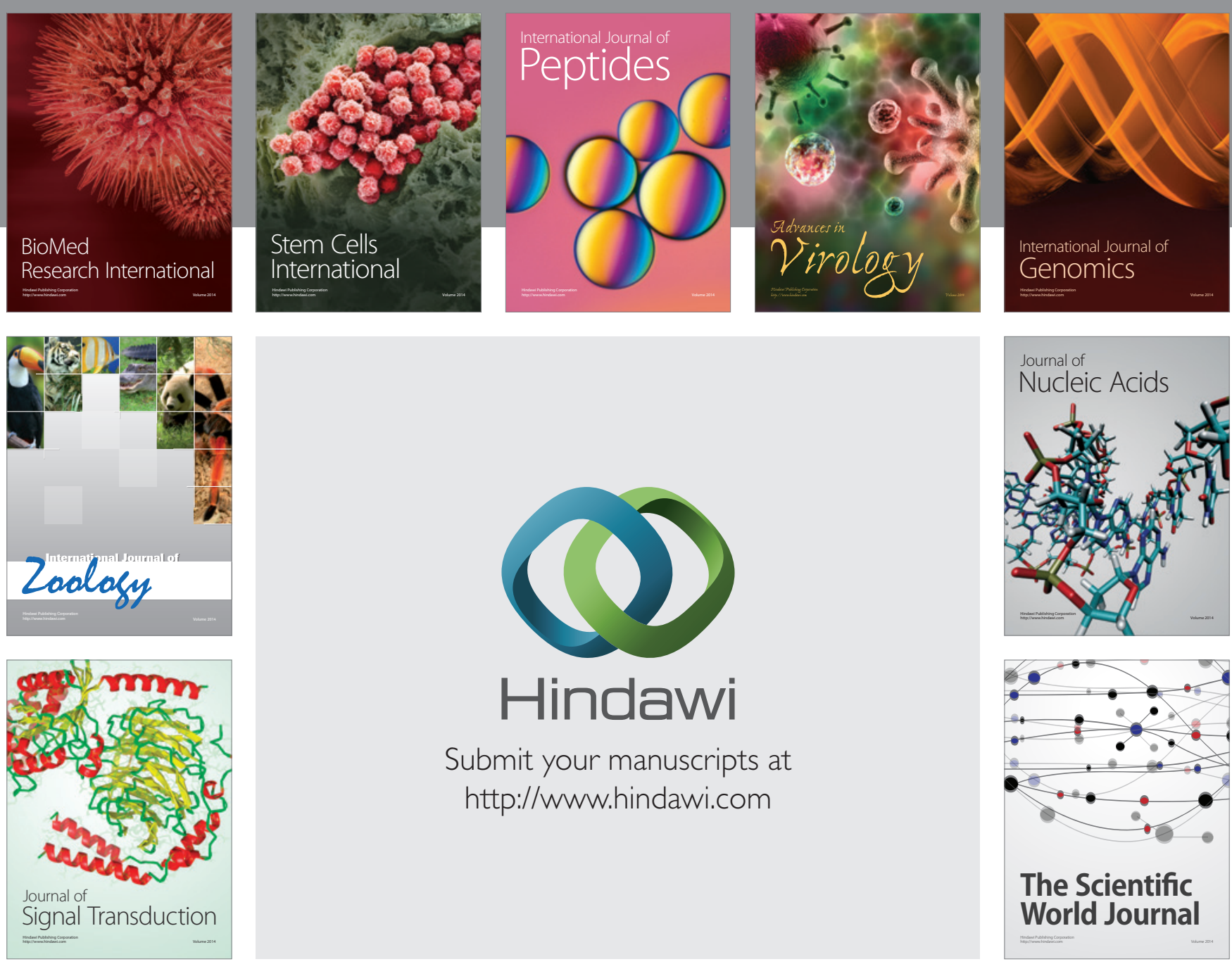

Submit your manuscripts at

http://www.hindawi.com
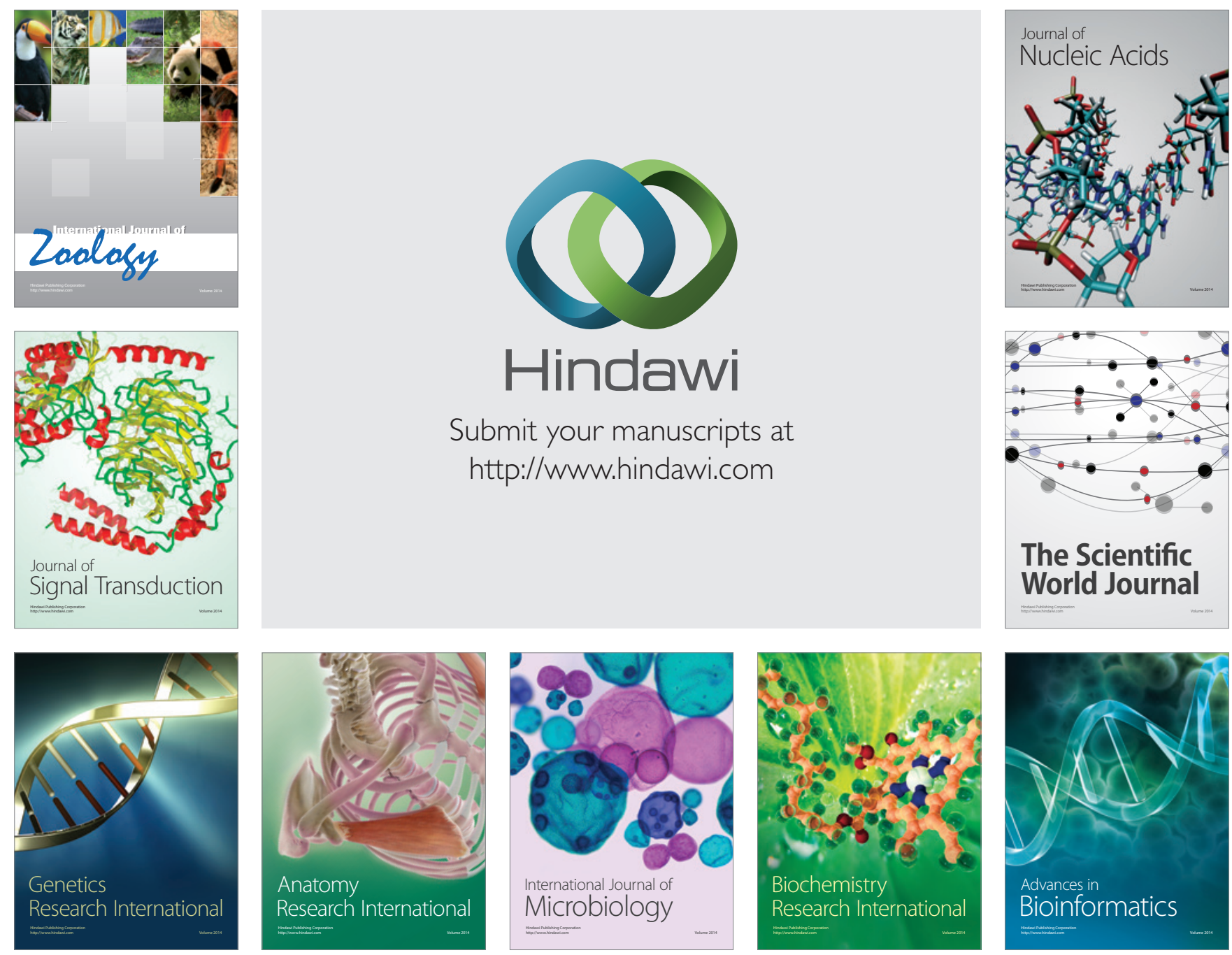

The Scientific World Journal
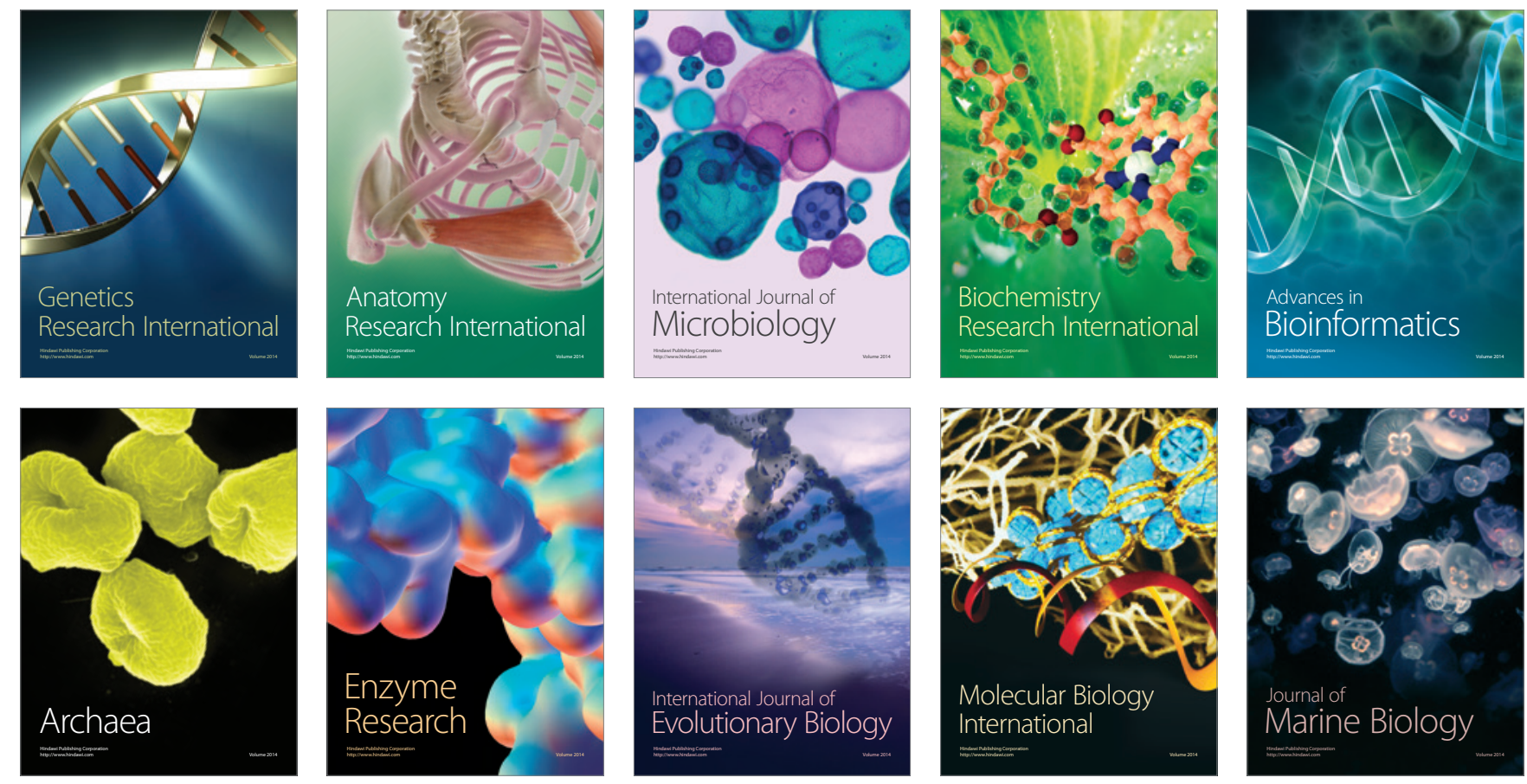